\title{
Chess movies między ludologią a historią wizualną - wprowadzenie do zagadnienia. Od Gorączki szachowej (1925) po Gambit królowej (2020)*
}

Chess movies between ludology and visual history: An introduction. From Shakhmatnaya goryachka (1925) to The Queen's Gambit (2020)

\section{Jacek Szymala}

Uniwersytet Wrocławski

historiawkinie@gmail.com | ORCID: 0000-0002-8714-7114

\begin{abstract}
The article is an attempt to classify the so-called chess movies chess films, films about chess and films about chess players. The text lists and characterizes selected films from among 83 included in the filmographic overview. The author proposes an interdisciplinary research approach combining elements of ludology and visual history. Each movie tells us something about the time it was made, including the history of chess and how it was perceived during that historical period.
\end{abstract}

Keywords: chess movie, chess film, Shakhmatnaya goryachka, The Queen's Gambit 
* Za zapoznanie się z maszynopisem tekstu oraz konsultacje dziękuję instruktorowi szachowemu Adamowi Szymali i FM Henrykowi Seifertowi. Artykuł dedykuję wszystkim szachistom, z którymi grałem i zagram. 


\section{Wstęp. Propozycje typologii}

Szachy były, są i będą obecne w filmach. Jeśli ta obecność dotyczy większości czasu ekranowego, mówimy o chess movie, czyli filmie szachowym w sensie ścisłym. Filmy zawierające motywy lub wątki szachowe posiadają elementy (ujęcia, sceny, sekwencje) chess movies. Temat gry w szachy w (masowej) kulturze wizualnej spopularyzował film fabularny Ukryta gra i zwłaszcza serial wyprodukowany przez Netflix, Gambit królowej. Premiery tych dwóch obrazów w końcu drugiej dekady XX w. stanowią punkt wyjścia poniższych rozważań. Przy podjęciu próby klasyfikacji filmów szachowych - chess movies (zob. Giżycki, 1960 i późn.; Gryz, 2016; Chess.com, 2018; Włodarczyk, 2020) - nasuwa się także sposobność do uporządkowania tego zagadnienia. Artykuł rozpoczęty zostanie więc propozycją teoretycznych rozstrzygnięć, następnie scharakteryzowane zostaną (w kolejności chronologicznej) wybrane realizacje fabularne, na końcu natomiast zamieszczono filmografię zawierającą 83 tytuły w ujęciu alfabetycznym, także spoza omówionych w tekście głównym.

Nauki ścisłe badają szachy funkcjonalnie, jako przykład wariacji logicznych, statystyki i procesów decyzyjnych czy uczenia SI. Historia zaś zajmuje się ich funkcjonowaniem, symboliką, procesami genezy i transformacji stylistycznych, zmian w regułach itd. Historia szachów jest też istotnym przedmiotem w ramach kursów dla instruktorów szachowych. Badane i opracowywane są biografie szachistów i historie turniejów, w różnych aspektach, także przykładowo historia życia codziennego szachistów (zob hasło przedmiotowe „history of chess” w portalu academia.edu obserwowane przez ponad 5000 badaczy; zob. też np. Bubczyk, 2003 i 2009; Niemiec, 2011; Sołtysiak, 2014). Jeśli szachy pojawiały się w tekstach literackich, stawały się obiektem badań historyków literatury, literaturoznawców, filologów (ostatnio zob. książkę filmoznawcy-szachisty: Marszałek, 2019; zob. Dorwing, $\left.2019^{1}\right)$. Gdy mówimy o szachach w filmach, moglibyśmy je zaklasyfikować do nurtu tzw. filmów sportowych (gatunek ten obejmuje filmy fabularne dotyczące sportu, zob. szerzej: Kowalczyk, 2017). Nurt ten

\footnotetext{
${ }^{1}$ Jest to rozprawa doktorska przedstawiona na Uniwersytecie w Tallinie 13 listopada 2019. Za udostępnienie elektronicznej wersji pracy dziękuję recenzentowi tego doktoratu, prof. Andriejowi Rogatchevskiemu z UiT The Arctic University of Norway.
} 
jest dość reprezentatywny, ma także określone tradycje badawcze w ramach filmoznawstwa (wśród filmów i ich analiz przeważają obrazy poświęcone sportom bardziej dynamicznym i z tego względu dobrze sprawdzającym się na ekranie; zob. Wierski 2014). Andrzej Gryz na początku opracowania poświęconego filmowym szachistom stwierdził, że:

Spośród wszystkich filmowych ujęć sportowych potyczek rozgrywka szachowa odznacza się wyraźną odrębnością. Jest to materia trudna, niefotogeniczna i nazbyt statyczna. Unikatowy styl jej obrazowania znajduje uzasadnienie w samej logicznej architekturze królewskiej gry - pozbawionej elementów przypadkowości, cechującej się matematyczną abstrakcyjnością i wariacyjnością (Gryz 2016).

Nie do końca można się z tym zgodzić, zwłaszcza jeśli przyjrzeć się turniejom szachów błyskawicznych, obfitujących w dynamiczne uderzenia w zegary szachowe i parasportowe zachowania takie jak stawianie bierek pomiędzy polami, równoczesne przesuwanie figur lub pionów po szachownicy, interwencje sędziowskie etc.

Jeśli weźmiemy na warsztat filmowe portrety rzeczywistych szachistów lub przynajmniej prawdopodobnych zdarzeń (turniejów, miejsc, klimatu epoki itd.), filmy szachowe możemy zaklasyfikować jako przedmiot badań historii wizualnej - będą to fragmenty (lub mikrohistorie) historii wizualnej szachów. Jeśli przyjmiemy, że do historii wizualnej zalicza się także popularyzacja historii i dydaktyka historii, pojawia się kolejna perspektywa badawcza - przyglądanie się poszczególnym filmom jako utworom popularyzującym historię oraz motywującym do podjęcia nauki gry w szachy. Perspektywa metodologiczna historii wizualnej jest przydatna, ponieważ zwalnia z faworyzowania (w analizach) obrazów uznanych za artystycznie udane i pozwala na neutralny ogląd szerszej grupy filmów. Również rozpatrując chess movies, będę czerpał w dużej mierze z doświadczeń historii wizualnej.

Elementem lub pierwiastkiem, który łączy szachy i filmy, jest funkcja ludyczna, zatem film szachowy to „rozrywka podwojona”. Oprócz na przykład korzyści finansowych czy prestiżowych, jakie pojawiają się na poziomie mistrzowskim, szerszej grupy ludzi dotyczą szachy w znaczeniu amatorskim, „kawiarnianym”, nierankingowym. Podobnie jako jedną z głównych cech filmów wymienia się właśnie rozrywkę - nawet 
jeśli wyróżnilibyśmy kategorię filmów badawczych, naukowych, oświatowych czy instruktażowych (szczególnie dotyczących szachów, w rodzaju zamieszczanych w internecie samouczków lub po prostu rejestracji przebiegu turniejów), trzeba pamiętać o znanej już w starożytności korelacji „bawiąc - uczyć”. Oczywiście optymalnym podejściem (przygotowaniem) badawczym byłoby takie, przy którym badacz jest jednocześnie praktykiem - graczem szachowym (choć warunek ten nie jest konieczny wśród widzów, zwłaszcza jeśli potraktujemy kino jako sztukę filmową; wówczas im wyższy poziom artystyczny, tym mniejsza zachodzi presja, aby widz był jednocześnie szachistą - dobry film o szachach powinien być zrozumiany także przez nieszachistów).

Przedfilmowa historia wizualna szachów nie była dotąd, jak się zdaje, przedmiotem badań. Owszem, zajmowano się szachami z punktu widzenia historii sztuki, biorąc na warsztat różnorodne formy i materiały figur czy szachownic w różnych okresach historycznych i kręgach kulturowych, natomiast nie podjęto dotąd badań z punktu widzenia historii wizualnej (w odróżnieniu od historii sztuk wizualnych - nienastawionej na wartości artystyczne). Przykładowo interesujących wniosków mogłyby dostarczyć badania recepcji (rozpowszechniania, przyjmowania się) w poszczególnych krajach zestawów szachowych typu Staunton wprowadzonych w połowie XIX w. Badania takie pojmowane być mogą metodologicznie jako zjawiska globalne, te zaś umieścić można w tym przypadku w ramach historii wizualnej.

Nie każdy film z motywami szachowymi możemy ściśle zaklasyfikować jako film szachowy. Roboczo daje się wydzielić kilka grup lub konstelacji film-szachy:

1. filmy, w których szachy są podstawowym tematem fabuły i pełnoprawnym elementem pierwszoplanowym; są "bohaterem”; ta grupa najściślej odpowiada chess movies i będzie mnie najbardziej interesowała w tym opracowaniu;

2. filmy, w których szachy są metaforą: życia, śmierci, wojny etc. (przy czym nie muszą być główną lub jedyną metaforą w danym filmie) - grupa ta także może być rozpatrywana jako chess movies;

3. filmy, w których szachy są elementem stylistycznym i estetycznym, odgrywają rolę rekwizytu (zwłaszcza niemającego przełomowego znaczenia dla fabuły); 
4. filmy odwołujące się do fragmentu motywu szachów w kulturze $\mathrm{i}$ ich znaczenia: piony, gambit, figury, szach-mat etc.

Grupy 3 i 4 można sprowadzić do jednej jako filmy z motywami szachowymi. Przykładowo, filmem szachowym z grupy pierwszej nie będą adaptacje Alicji w Krainie Czarów lub serial Dom z papieru; filmy te posiadają tylko pojedyncze cechy chess movies i zliczenie ich wszystkich zdaje się karkołomne, a w każdym razie nie jest celem artykułu.

W tym opracowaniu skupię się na chronologicznym przedstawieniu pełnometrażowych filmów fabularnych, zwłaszcza tzw. głównego nurtu, a więc szeroko dystrybuowanych. Filmy dokumentalne dotyczące szachów wydają się łatwiejsze w zaklasyfikowaniu do chess movies, z tego względu, że przeważnie są to próby rekonstrukcji (fragmentów) biografii szachisty lub wizualne zapisy turnieju bądź rozgrywek; często też sam tytuł jest instruktywny i wskazuje na szachy bezpośrednio. Spośród filmów dokumentalnych wartych głębszych analiz i omówień przejrzałem w ramach badań wstępnych katalog filmów czarnogórskich i o Czarnogórze oraz polskie Repozytorium Filmoteki Narodowej. Spośród filmów o Czarnogórze wyróżnić można trzy chess movies: w 1950 r. powstał półgodzinny dokument Šahovska olimpijada u Dubrovniku (w tytule chodzi o IX Olimpiadę Szachową: na jej temat zob. Gawlikowski, 1978, s. 118-127), w którym pokazano wycieczkę zawodników do Kotoru, Cetyni i Budvy (Kastratović, 2006, s. 230). Cztery lata później zrealizowano dokument Sa Żenskog Šah turnira (Herceg Novi), czyli film z turnieju kobiecego w wymienionym mieście (Kastratović, 2006, s. 231), a z 1966 r. pochodzi Dama G-6 - filmowa biografia Svetozara Gligoricia, zrealizowana podczas turnieju w Titogradzie. Natomiast po wpisaniu słowa „szachy” w Repozytorium Filmoteki Narodowej uzyskałem 23 wyniki, w tym ponad sześciominutowy materiał na temat Błyskawiczny turniej szachowy z $1951 \mathrm{r}$. (film nie wszedł do żadnego z wydań Polskiej Kroniki Filmowej). Pozostałe odnalezione tam polskie filmy dokumentalne, które można zaklasyfikować jako chess movies, to w kolejności chronologicznej: Turniej szachistów. Mistrzostwa szachowe Polski w Katowicach (PKF 1946, nr 35); Zabrze. Szachowe mistrzostwa górników (PKF 1948, nr 10); Międzynarodowy turniej szachowy (PKF 1949, nr 3); Mistrz szachowy (PKF 1951, nr 21); Mistrz świata w szachach / Petrosjan (PKF 1963, nr 23a). Wykonałem także kwerendę w katalogu Wytwórni Filmów Oświatowych w Łodzi: w zbiorze blisko 5000 filmów nie udało 
się znaleźć żadnego spełniającego kryterium chess movie. Spośród filmów polskich, tematów lub motywów szachowych z pewnością wiele można uzyskać, przeszukując katalogi archiwów telewizyjnych. Na razie jednak przejdę do filmów fabularnych. Kryterium chronologiczne jest zasadne, ponieważ film definiowany zgodnie $\mathrm{z}$ historią wizualną może stanowić źródło historyczne do czasów, w jakich powstał. Większość scharakteryzowanych dalej przykładów wpisuje się w pierwszą grupę proponowanego rozumienia chess movies, natomiast ze względu na wprowadzający charakter tego opracowania wymienię także niektóre filmy bliższe grupie 2 (Siódma pieczęć) oraz 3-4 (akapit o serialach).

\section{Chess movies w pierwszej połowie $\mathrm{XX} \mathrm{w}$.}

W pierwszej połowie XX w. powstało znacznie mniej filmów szachowych niż po 1945 r. (z okresu przed 1925 r. zob. np. scenę gry w szachy Man Raya z Marcelem Duchampem w surrealistycznym filmie Rene Claire'a Antrakt, zob. International..., s, 381). Lata 20. i 30. nie zostały w tym względzie należycie opracowane; swojego opracowania doczekał się natomiast temat wątków szachowych w literaturze rosyjskiej tego okresu (Dorwing 2019; znamienne, że w drugim rozdziale dysertacji, poświęconym szachowym tematom i motywom, zabrakło filmów). Należy wymienić krótką niemą komedię Wsiewołoda Pudowkina Gorączka szachowa (1925) z ówczesnym mistrzem świata Josém Raúlem Capablancą w roli samego siebie (na temat filmu zob. np. International..., s. 787). Produkcja przypominała „ekscentryczne i zabawne pomysły [Lwa] Kuleszowa (powstała zresztą przy udziale niektórych współpracowników [jego] laboratorium)" (Wojnicka, 2009, s. 529). W 1928 r. opublikowano powieść satyryczną Dwanaście krzeseł. Akcja rozgrywa się współcześnie w Odessie, głównym bohaterem jest Ostap Bender, nazywamy przez siebie Wielkim Kombinatorem. W pierwowzorze literackim i radzieckich adaptacjach filmowych (Bendera brak w adaptacji polsko-czechosłowackiej, reż. M. Waszyński, M. Frič, 1933, pojawia się w filmie Gajdaja i serialu Zacharowa) występuje motyw szachów (na temat radzieckiego filmu Dwanaście krzeseł zob. Cybulski, 2014, rozdział 3.6). Sebastian Chosiński w recenzji filmu Leonida Gajdaja napisał m.in.: 
Brakuje pieniędzy? Można przecież sprzedawać bilety wstępu do miejsca, które jest ogólnie dostępne. Albo zorganizować, jak miało to miejsce w Wasiukach, turniej szachowy i zgarnąć kasę za każdą rozegraną partię. Wystarczy tylko przekonać - a raczej: oszukać - zapalonych szachistów, że jest się mistrzem świata w tej dyscyplinie (Chosiński, 2010).

W 1926 r. wydano książkę francuskiego dziennikarza Henri'ego Dupuy-Mazuela (1885-1962) Le Joueur d'échecs (Szachista). W tym samym roku powstała adaptacja filmowa, nazwana przez Jerzego Maśnickiego „najgłośniejszym polonicum filmowym lat 20.” (Maśnicki, 2006, zob. Kurkowska, Kurkowski, 2016, s. 244). Jest to fikcyjna (kontrfaktyczna, choć prawdopodobna) opowieść osadzona w realiach Rzeczypospolitej lat 70. XVIII w. Z końca lat 30. pochodzi druga filmowa adaptacja (z okrojoną fabułą, mniejszym rozmachem inscenizacyjnym) - dźwiękowy film Gracz w szachy w reżyserii J. Dréville'a (więcej na temat tego obrazu: Kurkowska, Kurkowski, 2016, s. 244-245). Oczywiste jest, że wojna zatrzymała twórczość kulturową, w tym filmową, i powstało znacznie mniej obrazów. Wymieńmy jeden wojenny (powstały w czasie wojny) chess movie: w 1944 r. Maya Deren, urodzona w Kijowie niezależna reżyserka, która przyjęła obywatelstwo amerykańskie, zrealizowała film pt. Na lądzie. Bohaterka (grana przez Deren) biegnie po plaży i angażuje się w partię szachów (na ten temat zob. International..., s. 259).

\section{Chess movies w okresie zimnej wojny}

Siódma pieczęć (reż. I. Bergman, 1957) stanowi inspirujący i wpływowy przykład filmu, w którym „szachy prowokują filozoficzne rozważania związane z opisem rzeczywistości” (Gryz, 2016). Rafał Marszałek stwierdził, że o historii w Siódmej pieczęci mówi się powściągliwie właśnie ze względu na to, że dla reżysera istotniejszy był namysł filozoficzny, zwłaszcza egzystencjalny. Jednak Marszałek przyznaje, że „[h]istoryk sztuki na przykład wyłowiłby z dzieła Bergmana obraz średniowiecznego rycerza dla porównania $\mathrm{z}$ innymi; historyk idei w sławnym obrazie pielgrzymki pątników znalazłby ekwiwalent pewnego typu religijności" (Marszałek, 1984, s. 444). W podobnym okresie (premiera w Wenecji w 1955 r., w USA w 1957) powstał znacznie mniej znany surrealistyczny film $8 \times 8$ : A Chess Sonata in 8 Movements (reż. H. Richter, J. Cocteau). Obraz 
charakteryzowano jako umiejscowiony „pomiędzy Freudem a Lewisem Carollem"; zagrali w nim artyści awangardowi, m.in. Jean Cocteau, Max Ernst, Marcel Duchamp; szachy występują w roli inspirującego wyobraźnię surrealistycznego rekwizytu (na temat gry w szachy ze śmiercią zob. np. International..., s. 1113).

W latach 60. pojawiło się kilka filmów, w których motywy szachów i szachistów miewały pewne znaczenie dla rozwoju fabuły, niekoniecznie jednak odsyłały do konkretnych turniejów, postaci czy znanych partii. Otwierająca bondowski film Pozdrowienia z Rosji (1963) sekwencja zawiera scenę przedstawiającą ostatnią partię rozgrywanego w Wenecji meczu Kronsteena z Czechosłowacji z Macadamsem z Kanady (na tablicy widać remisowy wynik 11,5/11,5). Czechosłowacki szachista wygrywa, ale widz-szachista dostrzeże, że ma nieprawidłowy odruch przełączania zegara dłonią, która nie wykonała ruchu. Gracze nie prowadzą zapisu mimo leżących na stoliku blankietów. Nazwisko „Kronsteen” kojarzy się z radzieckim arcymistrzem Davidem Bronsteinem (1924-2006), a filmowy mecz przypomina partię Bronsteina z Borysem Spasskim rozegraną podczas mistrzostw ZSRR w Leningradzie w 1960 r. (zob. Nguyen, 2017). Z połowy dekady pochodzi japoński film samurajski Zatôichi jigoku tabi (reż. K. Misumi), w 1966 r. miał premierę jugosłowiański obraz Rondo (reż. Z. Berković; szerzej na temat tego filmu zob. Pająk, 2018, rozdział Gra o ciało), rok później powstały dwa krótkie (po niecałe pół godziny) filmy polskie: Szach i mat! (reż. A. Zakrzewski) oraz Klub szachistów (reż. W. Lesiewicz). Ostatni oprócz tytułu ma niewiele wspólnego z omawianą grą. To adaptacja filmowa pozytywistycznej noweli Aleksandra Świętochowskiego; klub ma za zadanie zbierać wśród obywateli informacje o niemoralnych postępowaniach społeczeństwa.

W kontekście szachowym dają się ująć dwa filmy Stanleya Kubricka z lat 6o., oba zawierające sceny szachowe. Pierwszy to Lolita z 1962 r. (profesor Humbert uczy Charlottę Haze podstaw szachów w momencie, gdy jej nieletnia córka wchodzi do pokoju). Drugi tytuł to 2001: Odyseja Kosmiczna z 1968 r. Według Mikołaja Smykowskiego obraz ten jest „[j]ednym z pierwszych sygnałów nadejścia apogeum ery szachów komputerowych, który odbija się szerokim echem nie tylko w środowisku szachistów, ale przede wszystkim odbiorców kultury popularnej" (Smykowski, 2018, s. 134). W przełomowej dla fabuły filmu scenie rozgrywa się pojedynek 
szachowy: człowiek (kapitan statku Discovery One, Frank Poole) gra białymi, komputer (HAL 9000) czarnymi. Komputer wygrywa, stosując pięcioruchową kombinację i gambit - jak słusznie tłumaczy Smykowski, „urzeczywistniając tym samym (oczywiście na poziomie fikcji filmowej) fantazmatyczną wizję niepokonanej maszyny szachowej" (tamże, s. 135). Warto zauważyć, że współczesne Kubrickowi (filmowcowi-szachiście) komputery nie potrafiły wykorzystać taktycznego poświęcenia materiału - po raz pierwszy zaobserwowano to w maszynach z połowy lat 90., w słynnych meczach komputera z Kasparowem.

Również w 1968 r. miał premierę nagrodzony Oscarem film Afera Thomasa Crowna. Dwoje głównych bohaterów (role Steve’a McQueena i Faye Dunaway) w jednej ze scen gra w szachy. Nie jest to turniejowa, mierzona czasem zegara rozgrywka, z figurami typu Staunton; jest to natomiast pełna subtelnego erotyzmu gra znudzonego życiem milionera i agentki ubezpieczeniowej. Bohaterowie rozpraszają się mimiką, grająca czarnymi kobieta prowokuje przeciwnika, odchylając sukienkę i dwuznacznie dotykając gońca. W komentarzach internetowych powtarzało się określenie „najseksowniejsza partia”, zwracano także uwagę na walor muzyki w tej niemej (bohaterowie milczą) scenie, kulminacyjnej dla całego filmu.

Przełom lat 60. i 70. XX w. wydaje się przełomowy zarówno w historii szachów, jak i w historii szachów filmowych (szachów w filmach, filmów szachowych). 1972 rok, czyli datę meczu Roberta Fischera z Borysem Spasskim, i ogólnie karierę „Bobby’ego” Fishera uznaje się za przełomowe, dzielące historię szachów w XX w. na „przed” i „po”. Cezura ta jest symboliczną datą, jeśli historię szachowych mistrzostw świata umieści się w kontekście zimnej wojny i rywalizacji politycznej ZSRR (i państw satelickich) oraz USA (i innych krajów kapitalistycznych). Istotny był radziecki film Arcymistrz z 1973 r. z rolami arcymistrzów Michaiła Tala (1936-1992) i Wiktora Korcznoja (1931-2016) jako samych siebie. W filmie zamieszczono także ujęcie dokumentalne przedstawiające Olimpiadę Szachową w Skopje z 1972 r. (na jej temat zob. Gawlikowski, 1978, s. 402-444): przy szachownicach widzimy m.in. Tigrana Petrosjana (1929-1984), Paula Keresa (1916-1975) i Lajosa Portischa (ur. 1936). (Zob. Grandmaster [fragment filmu], bez daty). Znaczącym (dla historii szachów, historii politycznej, a także historii wizualnej szachów) faktem jest, że po emigracji Korcznoja do Szwajcarii w 1976 r., film został w ZSRR zabroniony, a sam 
szachista - napiętnowany jako uciekinier. Współcześnie wydarzenia te upamiętniono w filmie brytyjskim Antyszachy: 1978 Korcznoj kontra Karpow i Kreml z $2017 \mathrm{r}$.

$\mathrm{Z}$ lat 70. pochodzą też, jak wspomniałem, dwie adaptacje Dwunastu krzeset, zawierające wątek szachowy. Można także wymienić spektakl polskiego Teatru Telewizji w reżyserii O. Lipińskiej według komedii Aleksandra Fredry Damy i huzary. Żołnierze napoleońscy w domu Majora grają w szachy lub organizują polowania; spokój rozgrywki zakłóca pojawienie się kobiet. Zabawny wydźwięk i lekki ciężar gatunkowy ma także indyjski musical z 1977 r. pod tytułem Shatranj Ke Khilari (Szachiści, reż. R. Satyajit). Niekończące się partie szachów stanowią w filmie humorystyczną przeciwwagę dla powagi wielkiej polityki: bohaterowie prowadzą własną grę, podczas gdy ostatni niezależny kraj Indii trafia właśnie pod brytyjskie panowanie. Polityczny podtekst ma także powstała w 1974 r. krótkometrażowa irańska animacja pod tytułem Rokh (The Rook, polski tytuł: Szachy; dosłowne tłumaczenie: Wieża). To metaforyczna satyra: pozornie o niewinnej grze, ale może być postrzegana jako krytyka sił rządzących ówczesnym Iranem. W partii zostają zbite wszystkie figury i piony, po czym pozostaje remisowa sytuacja z dwoma królami: to bezpośredni komentarz do sytuacji w Iranie i regionie lat 70. (van de Peer, 2017, s. 62). Politycznych aluzji i ironicznego (antyburżuazyjnego) wydźwięku można się również dopatrywać w radzieckim musicalu D’Artagnan $i$ Trzej muszkieterowie (1978): d'Artagnan gra w szachy z kardynałem Richelieu, duchowny jest mu wdzięczny, że spatował (Chess motifs, bez daty; na temat filmu zob. Szymala, 2016, s. 68-69).

Kolejne dwie dekady zaowocowały równie interesującymi i wartymi szczegółowych analiz filmowymi obrazami szachów i szachistów. Jedynie je wymienię, aby przejść do omówienia tego wątku w bliższym współczesności okresie. Pod koniec 1980 r. miała premierę radziecka biografia filmowa Aleksandra Alechina (1892-1946, czwarty mistrz świata w szachach) pod tytułem Belyy sneg Rossii. Scena gry w szachy z Łowcy androidów (1982) przypomina pojedynek Adolfa Anderssena i Lionela Kieseritzky'iego z $1851 \mathrm{r}$. (Jraberl, 2018). W połowie lat 80. powstały m.in. następujące produkcje: Capablanca - radziecko-kubański fragment filmowej biografii poprzednika Alechina; Podwójny mat - komedia albańska o pracowniku branży rybnej, który stał się znany jako szachista. W 1985 r. film 
szachowy Przekątna gońca otrzymał Oscara w kategorii najlepszego obrazu zagranicznego. To francusko-szwajcarsko-liechtensteinowska koprodukcja z rolami polskich aktorów (Daniela Olbrychskiego i Wojciecha Pszoniaka) z akcją osadzoną w czasach zimnej wojny; kulminacyjny pojedynek dotyczy radzieckiego szachisty i jego ucznia. Za filmowy motyw szachowy symbolicznie zamykający okres zimnej wojny można uznać stwierdzenie kapitana Ramiusa z Polowania na Czerwony Październik (1990), który porównał morski aspekt zimnej wojny do partii szachów ZSRR-USA. W połowie lat 90. nie było już Związku Radzieckiego, a w filmach amerykańskich jako główny wróg zaczęły się częściej pojawiać cywilizacje pozaziemskie. Szachiści w filmach pozostali, przykładowo w Dniu Niepodległości (1996) szachistą jest David Levinson, który nieustannie opisuje inwazję Obcych, posługując się analogiami szachowymi (np. „szach-mat”).

\section{Chess movies ostatnich dwóch dekad (2000-2020)}

Pojawienie się dużej liczby filmów szachowych w latach 2000-2020 wiązać można z postępem technicznym, jaki dokonał się we wszystkich dziedzinach życia, w tym w domenie szachów (powszechne stały się rozgrywki wirtualne, nie kwestionowano już przewagi komputerów nad ludźmi w zakresie zdolności obliczeniowych, upowszechniły się zegary elektroniczne i wideotransmisje turniejów w czasie rzeczywistym on-line, poszerzono bazy partii itd.). Oczywiście w miarę postępu przybywa innych form gry i zabawy, a więc rola szachów może maleć, natomiast w dobie e-lekcji oraz różnorodności programów do nauki indywidualnej zmniejsza się także elitarność szachów i pojawiają się dodatkowe motywacje. W każdym razie szachami wciąż interesują się filmowcy (a więc i ich widzowie, przez co koło się zamyka.

Współcześnie, zwłaszcza po słynnych meczach Garriego Kasparowa z komputerem, filmowcy uzyskali więcej możliwości pokazywania szachów i szachistów w sposób „medialny”, bardziej dynamiczny. Powstała cała grupa filmów o pojedynkach człowiek-komputer (np. Kasparow kontra komputer; Computer Chess), a po upadku Związku Radzieckiego i zakończeniu zimnej wojny odświeżane bywają nawiązania do tych czasów, często posługujące się metaforami szachów (najczęściej związanych ze Związkiem 
Radzieckim ze względu na tradycyjną dominację tamtejszych szachistów). Wobec tego wyróżnia się szereg filmów o Robercie „Bobbym” Fisherze, czyli pierwszym amerykańskim (nieradzieckim) mistrzu świata w szachach. Filmy te to głównie Szachowe dzieciństwo z 1993 r., Bobby Fischer kontra reszta świata z 2011 r. i Pionek z 2014 r.; Fisher wzmiankowany jest też przykładowo w Incepcji z 2010 r., a totem bohaterki tego dzieła, Ariadny, to figura gońca.

Filmowe biografie szachistek pojawiły się dopiero w ostatniej dekadzie: trzeba wymienić Szachistkę (2009), Siostry Polgar (2014), Królowa Katwe (2016) i Gambit królowej (2020). W ostatnim z filmów (serial traktuję tu jako film podzielony na części) mamy do czynienia z uniwersalną opowieścią prawdopodobną, niekoniecznie opartą na życiorysie rzeczywistej szachistki, choć niektórzy doszukują się paraleli z karierą arcymistrzyni Nony Gapridaszwili (ur. 1941; zob. James, 2020). W Gambicie królowej głównego rywala bohaterki, radzieckiego mistrza Wasilija Bogrova, zagrał polski aktor Marcin Dorociński (którego zagraniczna widownia mogła kojarzyć z rolą Ryszarda Kuklińskiego w Jacku Strongu, a skojarzenie to powoduje kolejne - z zimną wojną).

Najbardziej nośnym (ze względu na język angielski i szeroką dystrybucję) filmowo-szachowym polonicum jest o rok wcześniejsza Ukryta gra z akcją także osadzoną w czasach zimnej wojny. Łukasz Muszyński w recenzji filmu słusznie stwierdził, że:

Pałac Kultury i Nauki [...] na ekranie zamienia się w pole bitwy między wywiadami. Bodajże pierwszy raz od czasów „Ekstradycji 3” polscy twórcy zdecydowali się wykorzystać socrealistyczny symbol stolicy - z jego plątaniną pomieszczeń, tajnych przejść i skrytek - jako miejsce akcji filmu. Pozostaje mieć nadzieję, że spełniony debiut Kośmickiego położy podwaliny pod budowę popkulturowego statusu gmachu (Muszyński, 2019).

Warto dodać, że Pałac Kultury i Nauki w rzeczywistości wielokrotnie stanowił arenę zawodów szachowych (mistrzostw Polski, mistrzostw Europy), można więc mówić o symbolicznym spotkaniu historii szachów $\mathrm{z}$ historią wizualną lub historią w przestrzeni publicznej ( $\mathrm{w}$ dziedzinie chess movies).

Celem dopełnienia przeglądu o wybrane przykłady filmów z 3 i 4 grupy zaproponowanej we wstępie klasyfikacji chess movies (filmy z motywami szachowymi, najdalsze od grupy 1 i najbardziej rozmyte, jeśli chodzi o przynależność do tej klasyfikacji) przejdę do zreferowania wątków 
szachowych we współczesnych polskich serialach telewizyjnych. 59 odcinek Świata według Kiepskich (1999 r.) rozpoczyna się sceną gry Ferdka z Waldkiem w szachy, a raczej zabawnego połączenia szachów, warcabów i gry w kości. Nazwa w pewnym sensie zapowiada skojarzeniowo akcję: w odcinku tym pojawi się arabski szejk, któremu Paździoch (rola Ryszarda Kotysa) sprzedał wrocławski Dworzec Główny za sto dolarów (w odcinku mamy więc nawiązania do różnych gier, w tym hazardowych). Szachy były wizualnym atrybutem dziadka Lucjana Mostowiaka (rola Witolda Pyrkosza) w M jak miłość (od pierwszych odcinków z 2000 r. po śmierć aktora w 2017) - przez to, że aktor do końca życia w nim występował, wśród części widzów Lucek-Pyrkosz będzie z nimi kojarzony. W polskiej wersji włoskiego Don Mateo - serialu Ojciec Mateusz (emisja od 2008 r.) tytułowy bohater (rola Artura Żmijewskiego) zaprzyjaźnia się z policjantem Mieczysławem Noculem i regularnie ogrywa go w szachy. Gra jest w Ojcu Mateuszu symbolicznym pomostem między wykształconym teologiem a nieco przaśnym, znacznie mniej rozgarniętym (choć nie mniej lubianym), podwładnym inspektora Możejki (w niektórych odcinkach partie policjantów ogląda ksiądz Mateusz, oczywiście podsuwając najlepsze posunięcia - podpowiada głównie Noculowi).

Kończąc przegląd, przywołam jeszcze kilka filmów spełniających kryterium pierwszej grupy proponowanej klasyfikacji chess movies, a powstałych w ostatnich latach. $Z$ pewnością należy wymienić filmy o obecnym (od 2013 r.) mistrzu świata Magnusie Carslenie (np. Magnus z 2016 r.). Natomiast przykładowo w polskim internecie po premierze Gambitu królowej powstał odrębny odcinek programu „Historia bez cenzury”, zatytułowany Gambit mędrca - historia szachów (2021). W pewnym więc sensie zauważamy konwergencję mediów: jeden chess movie inspiruje inny, a rzeczywiste pojedynki stanowią inspirację dla filmowców; być może także część społeczeństwa będzie usiłowała „grać jak bohater filmu” (być jak Beth z Gambitu królowej), a nie „tylko” jak rzeczywisty mistrz.

\section{Zakończenie}

Większość wymienionych tytułów to produkcje zachodnioeuropejskie lub amerykańskie, kilka powstało w ZSRR lub Rosji, niektóre w Polsce. 
Zadziwiający jest brak izraelskich filmów szachowych (zwłaszcza z pierwszej grupy), biorąc pod uwagę, że wielu szachowych arcymistrzów, w tym mistrzów świata, miało pochodzenie żydowskie (niektórzy w dwudziestoleciu międzywojennym reprezentowali Polskę, część po wojnie grała na konto Związku Radzieckiego). Nasuwa się postulat badań zakrojonych na szerszą skalę, natomiast dotychczasowa kwerenda (zob. tomy zbiorowe pod redakcją Joanny Preizner, dotyczące filmów żydowskich) pokazuje, że Izrael nie wyprodukował takich filmów lub ich grupa nie jest reprezentatywna dla kinematografii izraelskiej. Niektóre z filmów szachowych zostały nagrodzone Oscarem (Afera Thomasa Crowna, Przekątna gońca, Gra Geriego). W opisanym wyżej "gatunku” chess movies można zauważyć polonica: polscy aktorzy grywali radzieckich szachistów (Przekątna gońca, Gambit królowej).

Przykłady dobierałem tak, aby mieściły się w pierwszej z wymienionych czterech kategorii filmów szachowych. Okazało się, że niejednokrotnie jeden film można równocześnie zaklasyfikować zarówno jako film z motywami szachowymi, jak i taki, w którym figury lub nomenklatura szachowa odgrywają rolę rekwizytu, a filmowe „życie szachowe” stanowi metaforę. Trudno jednoznacznie odseparować od siebie zwłaszcza grupy 2, 3 i 4. Istotna jest także recepcja - otóż widz szachista prawdopodobnie zapamięta $\mathrm{z}$ filmu obraz rozstawionej szachownicy lub nazwisko szachisty, a więc element, który w zamyśle twórców zapewne miał stanowić jedynie niewiele wnoszący do fabuły rekwizyt. Wówczas klasyfikacja takiego filmu zmieni się na grupę 1. Postulowanym rozwiązaniem trudności definicyjnych na dalszych etapach badań będzie rozpatrywanie chess movies według innych grup: przykładowo szachowych filmów kobiecych, szachowych poloniców filmowych, filmowych portretów poszczególnych mistrzów świata, filmowej historii szachowej itd.

Mikołaj Smykowski pytał: „Czy szachy są (jeszcze) grą ludzką, czy (już) komputerową?" (Smykowski, 2018, s. 140). Na pytanie to można odpowiedzieć, że są grą coraz bardziej „filmową”. Powstaje coraz więcej chess movies, a także - czego dowodzi powyższy tekst - publikowane są opracowania tego zagadnienia (pojawia się więc świadomość „filmowości” tej gry). Powyższy przyczynek i poniższe zestawienie filmograficzne dowodzą, że chess movies mogą stać się inspirującym polem badań interdyscyplinarnych, w tym ludologicznych i z dziedziny historii 
wizualnej. Każdy z wymienionych filmów wymaga głębszych przemyśleń i solidniejszych analiz. Istotnym materiałem do badań porównawczych zdają się wypowiedzi szachistów, w tym wspomnienia, podręczniki, korespondencja i inne formy, zwłaszcza te, w których opisali swoje wrażenia po filmach szachowych. Interesujących źródeł mogą dostarczyć badania z wykorzystaniem historii mówionej - rozmowy badaczy z szachistami, również na temat filmów. Oczywiście należałoby także przepisać i przeanalizować filmowe partie.

Wśród wniosków do dalszych badań warto zasygnalizować potrzebę przyjrzenia się motywom szachowym w filmach animowanych. Chronologicznie byłyby to przynajmniej następujące tytuły: krótkometrażowa komedia Chess-nuts z 1932 r., Gra Geriego (film z 1998 r. nagrodzony Oscarem, o staruszku, który z braku przeciwnika postanowił grać ze sobą) oraz produkcja Disneya z tego samego okresu - Hercules, w której Hades demonstruje moc, ukazując wrogów przez kształty figur szachowych (Chess motifs, bez daty) ${ }^{2}$. Ustawienie mapy niczym szachownicy i fabułę przypominającą szachy dostrzeżemy też w animacji Pokémon 2: uwierz $w$ swoją siłę (tamże). Popularny w internecie jest krótki film animowany A brief history of chess, zamieszczony w $2019 \mathrm{r}$.

W podsumowaniu tego przyczynku zgodzę się z wnioskami, które zaproponowała Magdalena Kowalczyk w zakończeniu swojej dysertacji doktorskiej o filmach sportowych (Kowalczyk, 2017, s. 277-279). Recenzent sformułował je w sposób następujący: „sport podsunął kinematografii bardzo atrakcyjną, niezwykle charakterystyczną i zrozumiałą nieomal dla każdego ikonografię, szereg tematów, które łatwo było przełożyć na proste, ale interesujące scenariusze, niosące ze sobą najczęściej budujący wydźwięk i optymistyczne przesłanie" (Sokołowski, 2017, s. 6). Choć autorka skupiła się na innych sportach niż szachy (w tym tak jak one starszych od kina, np. narciarstwie, taternictwie), wszystkie zaproponowane kategorie chess movies na ogół łączy budujące przesłanie i pozytywny wydźwięk.

\footnotetext{
${ }^{2}$ Bogowie greccy przedstawieni w filmie Jazon i Argonauci z 1963 r. w kilku scenach także grają w grę podobną do szachów, w której przestawiają figury reprezentujące herosów i bohaterów filmu (zob. <https://tvtropes.org/pmwiki/pmwiki.php/Main/ChessMotifs >).
} 


\section{Filmografia}

2001: Odyseja Kosmiczna, reż. S. Kubrick, USA 1968.

$8 \times$ 8: A Chess Sonata in 8 Movements, reż. H. Richter, J. Cocteau, USA 1957.

A brief history of chess - Alex Gendler, 2019, film dostępny online: <https:// www.youtube.com/watch?v=YeB-1F-UKOo>.

Afera Thomasa Crowna, reż. N. Jewison, USA 1968.

Alicja po drugiej stronie lustra, reż. A. Bresciani, R. Slapczynski, Australia, Polska, USA, Włochy 1987.

Antyszachy: 1978 Korcznoj kontra Karpow i Kreml, reż. A Byron, Wielka Brytania 2017.

Archiwista, reż. R. Wichrowski, Polska 2020.

Arcymistrz, reż. S. Mikaelyan, ZSRR 1973.

Belyy sneg Rossii, reż. Y. Vyshinsky, ZSRR 1980.

Bobby Fischer kontra reszta świata, reż. L. Garbus, Islandia, USA, Wielka Brytania 2011.

Caissa, reż. M. Woźniak, Polska 2012.

Capablanca, reż. M. Herrera, Kuba, ZSRR 1987.

Chess game, reż. K. Grieve, R. Tucker, serial (6 odcinków), Wielka Brytania 1983.

Chess-nuts, reż. D. Fleischer, USA 1932.

Computer Chess, reż. A. Bujalski, USA 2013.

Czarne i białe jak dnie i noce, reż. W. Petersen, RFN 1978.

Czarny koń, reż. T. Solondz, USA 2011.

Dama G-6, reż. M. Fehimović, Jugosławia 1966.

D’Artagnan i trzej muszkieterowie, reż. G. Yungvald-Khilkevich, ZSRR 1978. Damy i huzary, reż. O. Lipińska, Polska (Teatr Telewizji) 1973.

Dwanaście krzeset, reż. L. Gajdaj, ZSRR 1971.

Dwanaście krzeset, reż. M. Zacharow, ZSRR 1976.

Dzień Niepodległości, reż. R. Emmerich, USA 1996.

El jugador de ajedjez, reż. L. Oliveros, Hiszpania 2017.

Fahim, mały książę szachistów, reż. P. Martin-Laval, Francja 2019.

Fresh, reż. B. Yakin, Francja, USA 1994.

Gambit królowej, reż. S. Frank, A. Scott, USA 2020.

Gambit mędrca - historia szachów, reż. B. Drewniak, cykl Historia bez cenzury, 2021. 
Gierka, reż. E. Oppenheimer, USA 2014.

Gorączka szachowa, reż. W. Pudowkin, ZSRR 1925.

Gracz w szachy, reż. J. Dréville, Francja 1938.

Gra Geriego, reż. J. Pinkava, USA 1997.

Harry Potter i Kamień Filozoficzny, reż. C. Columbus, USA, Wielka Brytania 2001.

Hercules, reż. J. Musker, R. Clements, USA 1997.

Incepcja, reż. Ch. Nolan, USA 2010.

Jazon i Argonauci, reż. D. Chaffey, USA 1963.

Kasparow kontra komputer, reż. V. Jayanti, Kanada, Wielka Brytania 2003.

Klub szachistów, reż. W. Lesiewicz, Polska 1967.

Królowa Katwe, reż. M. Nair, USA 2016.

La Partie d'echecs, reż. Y. Yanchar, Belgia, Francja, Szwajcaria 1994.

Lolita, reż. S. Kubrick, USA 1962.

Łowca androidów, reż. R. Scott, USA 1982.

M jak miłość, wielu reż., Polska 2000-2017 (odc. 1-1329).

Magnus, reż. B. Ree, Norwegia 2016.

Międzynarodowy turniej szachowy (PKF 1949, nr 3).

Mistrz szachowy (PKF 1951, nr 21).

Mistrz świata w szachach/ Petrosjan (PKF 1963, nr 23a).

Mordercza rozgrywka, reż. C. Schenkel, USA 1992.

Na lądzie, reż. M. Deren, USA 1944.

Najniebezpieczniejsza partia (odc. serialu Columbo), 1973.

Nowela szachowa, reż. G. Oswald, Niemcy (RFN) 1960.

Obrona Łużyna, reż. M. Gorris, Francja, Wielka Brytania 2000.

Ojciec Mateusz, wielu reż., serial, Polska 2008-2020.

Pionek, reż. E. Zwick, USA 2014.

Planeta Kirsan, reż. M. Pięta, Polska 2010.

Playing Chess, reż. G. Cooper, USA 2014.

Podwójny mat, reż. B. Kapexhiu, Albania 1986.

Pokémon 2: uwierz w swoją siłę, reż. K. Yuyama, M. Haigney, USA 1999.

Polowanie na Czerwony Październik, reż. J. McTiernan, USA 1990.

Pozdrowienia z Rosji, reż. T. Young, Wielka Brytania 1963.

Przekątna gońca, reż. R. Dembo, Francja, Szwajcaria 1984.

Przypadek Pekosińskiego, reż. G. Królikiewicz, Polska 1993.

Rondo, reż. Z. Berković, Jugosławia 1966. 
Rycerze Południowego Bronksu, reż. A. Hughes, USA 2005.

Sa Żenskog Šah - turnira (Herceg Novi), Jugosławia 1954.

Siostry Polgar. Jak wychować szachowe mistrzynie, reż. Y. Aviram, Izrael, USA, Węgry 2014.

Siódma pieczęć, reż. I. Bergman, Szwecja 1957.

Son of the gun, reż. J. Avery, Australia, Kanada, Wielka Brytania 2014.

Szach-mat, reż. J. Goldberger, USA 2013.

Szach i mat!, reż. A. Zakrzewski, Polska 1967.

Szachista, reż. P. Matyja, Polska 2020.

Szachistka, reż. C. Bottaro, Francja, Niemcy 2009.

Szachiści, reż. S. Ray, Indie 1977.

Szachowe dzieciństwo, reż. S. Zaillian, USA 1993.

Szachowa zagrywka, reż. N. Santa, Kolumbia 2017.

Szachy, reż. A. Akbar Sadeghi, Iran 1974.

Šahovska olimpijada u Dubrovniku, Jugosławia 1950.

Turniej szachistów. Mistrzostwa szachowe Polski w Katowicach (PKF 1946, nr 35).

Ukryta gra, reż. Ł. Kośmicki, Polska 2019.

Vinci, reż. J. Machulski, Polska 2004.

Zabrze. Szachowe mistrzostwa górników (PKF 1948, nr 10);

Zatôichi jigoku tabi, reż. K. Misumi, Japonia 1965.

Zdradzieckie gry miłosne, reż. J. Krejčík, Czechosłowacja 1971.

\section{Literatura}

Bubczyk, R. (2003). Gry w szachy i kości jako rozrywki duchowieństwa w średniowiecznej Polsce. Annales Universitatis Mariae Curie Skłodowska Lublin - Polonia. Sectio F. Historia, nr 58, 25-33.

Bubczyk, R. (2009). Gry na szachownicy w kulturze dworskiej i rycerskiej w średniowiecznej Anglii na tle europejskim. Lublin: Wydawnictwo Uniwersytetu Marii Curie-Skłodowskiej.

Chess.com (1 października 2018). 7 Chess Movies You Do Not Want To Miss. Online: <https://www.chess.com/article/view/chess-movies>. Chess motifs (bez daty). [Wyszukiwarka motywów szachowych, różni autorzy, różne daty publikacji haseł]. Online: <https://tvtropes.org/ pmwiki/pmwiki.php/Main/ChessMotifs>. 
Chosiński, S. (27 kwietnia 2010). Ostap Bender - bohater swoich czasów! [L. Gajdaj, 12 krzeseł - recenzja]. Online: <https://esensja.pl/film/dvd/ tekst.html?id=9582\&strona $=2>$.

Cybulski, M. (2014). ZSRR się śmieje. Filmy Leonida Gajdaja i radziecka kinematografia komediowa. Toruń: Wydawnictwo Naukowe Grado.

Dorwing, D. (2019). Fienomien szachmatnoj igry $w$ russkoj litieraturie 1920-1930 gg. Tallin: niepublikowana praca doktorska.

Gawlikowski, S. (1978). Olimpiady szachowe 1924-1974. Wydanie 2. rozszerz. Warszawa: Wydawnictwo „Sport i Turystyka”.

Giżycki, J. (1960, 1972, 1984, 2020). Z szachami przez wieki i kraje. Warszawa: Sport i Turystyka.

Grandmaster [fragment filmu] (1973). Materiał opublikowany 28 kwietnia 2019 roku. Online: <https://www.youtube.com/watch?v=apf343hqoIw>. Gryz, A. (2016). Poza czernią i bielą. Filmowi szachiści. Ekrany, nr 1. Online: $<$ http://ekrany.org.pl/historia_kina/poza-czernia-i-biela-filmowiszachisci/>.

James, J. (5 grudnia 2020). "Emocyonalnost dajet o siebie znat". Nonagaprindaszwili - o sieriale Netflix i igrie w szachmaty s mużczina [wywiad z Noną Gapridaszwili]. Online: <https://www.bbc.com/russian/features-55188483>.

Jraberl (3 czerwca 2018, post). Chess and Blade Runner. Online: <https:// www.chess.com/forum/view/fun-with-chess/chess-and-blade-runner>.

Kastratović, G. (2006). Istorija crnogorskog filma. Podgorica: CID.

Kowalczyk, M. (2017). Film sportowy jako gatunek. Katowice: niepublikowana praca doktorska.

Kurkowska, M., Kurkowski, J. (2016). Studia Europejskie, nr 3, s. 213-231.

Marszałek, R. (2019). Niedoczas. Gdańsk: Wydawnictwo słowo/obraz terytoria.

Maśnicki, J. (2006). Niemy kraj. Polskie motywy w europejskim kinie niemym (1896-1930). Gdańsk: Wydawnictwo słowo/obraz terytoria.

Muszyński Ł. (2019). Gambit królewski [Ł. Kośmicki, Ukryta gra - recenzja]. Online: <https://www.filmweb.pl/reviews/recenzja-filmu-Ukryta+gra-22941>.

Nguyen, P. (8 lipca 2017). James Bond i szachy. Online: <https://infoszach. $\mathrm{pl} / 2017 / 07 / 08 /$ james-bond-i-szachy/>. 
Niemiec, D. (2011). Czy Konrad Mazowiecki grał w szachy na Wawelu? W: K. Dzięgielewski, Ł. Oleszczak (red.), Po drugiej stronie. Raporty przyjaciót-archeologów dla Wojtka Cholewy „Jonesa” (s. 195-206). Pękowice: Wydawnictwo i Pracownia Archeologiczna Profil Magdalena Dzięgielewska.

Pająk, P. (2018). Arcydzieła chorwackiego filmu fabularnego. Warszawa: Wydział Polonistyki Uniwersytetu Warszawskiego.

Peer, S. van de (red.) (2017). Animation in the Middle East. Practice and aesthetics from Gabhdad to Casablanca. London - New York: I. B. Tauris.

Pendergast, T., Pendergast, S. (red.) (2000). International dictionary of films and filmmakers (t. 1-4). St James Press.

Smykowski, M. (2018). Szachy - (nie)ludzka gra. Ludzie, maszyny i antycypacje przyszłości. Kultura Wspótczesna, 26(2), 132-142.

Sokołowski, M. (2017). Recenzja rozprawy doktorskiej Pani Magister Magdaleny Kowalczyk Film sportowy jako gatunek napisanej pod kierunkiem Prof. zw. dr hab. Tadeusza Miczki, Katowice 2017, ss. 292. Online: <https:// www.fil.us.edu.pl/wp-content/uploads/2016/11/Kowalczyk_recenzja_ Soko\%C5\%82owski.pdf>.

Sołtysiak, M. (2014). Archeologia szachów. Przyczynek do badania zmian kulturowych dotyczących pozycji kobiet w średniowieczu, na przykładzie transformacji figury wezyra w królową. Homo Ludens, 6(1), 153-170.

Szymala, J. (2016). Zamki w Olesku i Podhorcach jako obiekty turystyczne i miejsca realizacji filmów historycznych. W: J. Szymala, Film - Historia - Turystyka (s. 68-69). Kraków: Księgarnia Akademicka.

Wierski, D. (2014). Sport w polskim kinie 1944-1989. Gdańsk: Wydawnictwo Naukowe Katedra.

Wojnicka, J. (2009). Kino Rosji carskiej i Związku Sowieckiego. W: T. Lubelski, I. Sowińska, R. Syska (red.), Kino nieme (s. 529). Kraków: Universitas.

Włodarczyk R. (16 lipca 2020). 10 filmów szachowych. Online: <https:// naszachownicy.pl/10-filmow-szachowych>.

Data dostępu do źródeł internetowych wykorzystanych w tekście: 11 listopada 2021 roku. 
dr Jacek Szymala - historyk, kulturoznawca, geograf, (współ)autor lub (wspót) redaktor siedmiu monografii i tomów zbiorowych oraz kilkudziesięciu artykułów naukowych.

\title{
Chess movies między ludologią a historią wizualną - wprowadzenie do zagadnienia. Od Gorączki szachowej (1925) po Gambit królowej (2020)
}

\begin{abstract}
Abstrakt: Celem artykułu jest sklasyfikowanie tzw. chess movies - filmów szachowych, o szachach i szachistach. W tekście wymieniono i scharakteryzowano wybrane tytuły spośród 83 ujętych w zestawieniu filmograficznym. Autor proponuje interdyscyplinarne ujęcie badawcze łączące elementy ludologii i historii wizualnej. Każdy film mówi coś o czasie, w którym powstał, w tym o historii szachów $i$ ich postrzeganiu $w$ danym okresie historycznym.
\end{abstract}

Słowa kluczowe: chess movie, film szachowy, Goraczka szachowa, Gambit Królowej. 